\title{
A study of the Causes of Schedule overrun in Indian High-rise construction using Relative Importance Index
}

\author{
Aaditya Pratap Sanyal (Author) \\ Department of Architecture and Planning \\ Indian Institute of Technology Kharagpur \\ Kharagpur, India \\ apsanyal@iitkgp.ac.in
}

\author{
S. P. Bhattacharya (Author) \\ Department of Architecture and Planning \\ Indian Institute of Technology Kharagpur \\ Kharagpur, India \\ spb@arp.iitkgp.ernet.in
}

\begin{abstract}
Construction projects across the world are plagued with time and schedule overruns. Schedule overruns are caused due to a wide range of factors associated to site-related issues to the issues related to payment. Although the principal reasons for construction delays are comparable across different locations within a country, several factors pertaining to local industry, socio-economic issues, cultural effects and project characteristics also contribute to construction delays. Through a series of studies performed across the past few decades, it has been seen that the causes and extent of schedule overruns varies across different countries and no universal causes of delay have been identified. On these grounds, it can also be hypothesised that in a country as diverse as India, the causes of delay may vary across different states and regions.
\end{abstract}

This research tries to ascertain the causes of schedule overrun associated to the various construction project locations in India, identified through a questionnaire survey and analysed using statistical methods. The findings of this study suggest that though there are certain similarities in the delay causes, but there is a difference between their relative importances. There are certain unique causes specific to some locations.

Keywords-delay factors; high-rise; India; construction

\section{INTRODUCTION}

A construction project is an interpretation of an idea through a series of actions to produce either a new set of buildings and infrastructure or may involve alterations in the existing buildings and infrastructure. Construction projects involve varying degrease of complexity and the project duration can be range from few weeks to more than five years. However, in some cases, the duration may be very long. For example, the Sardar Sarovar Project of India which took almost 60 years to become operational [1]. Construction schedule overrun or delay can be simply defined as non-completion of project within the specified duration agreed upon in the contract. Delay can also be defined as the time overrun either beyond completion date specified in a contract, or beyond the date that the parties agreed upon for delivery of a project [2]. Schedule overrun or delays, apart from upsetting the plan targets, leads to cost overrun on account of inflationary increase, exchange rate variation and higher interest and administrative cost. Delays takes place due to factors such as paucity of financial resources, delay in obtaining clearances, delay in acquisition of land, poor performance of consultants, vendors and contractors, disputes and court cases, inadequate infrastructure support, resistance by land losers and poor law and order [3].

Schedule overrun has also been defined as "the extension of time beyond planned completion dates traceable to the contractors" [5]. Schedule overruns, also generally termed as delays, are "incidents that impact a project's progress by postponing project activities". Studies in construction activities from an array of countries, namely, Hong Kong, India, the United States, Thailand, Saudi Arabia, Nigeria and Ghana showed that delay is a plebeian issue and an increasing concern irrespective of a countries development status or geographic location [6].In the recent past, studies have been performed by Akintoye et al. [7], Khanh et al. [8], Aziz [9], Gunduz et al. [10], Sweis et al. [11], Vimonsatit et al. [12], Fugar et al. [13], Ogunlana et al. [14] and, Toor et al. [15] for identifying the construction delay causes in Malaysia, Bangladesh, Egypt, Turkey, Jordan, Western Australia, Ghana, Vietnam and Thailand respectively. The findings of these studies were varied with most of the researches confirming financial difficulties, project planning and scheduling inefficiencies as some of the key important causes.

In order to understand the delay causes facing the Indian construction industry, a detailed study performed by Doloi et al. [17] suggested that construction projects in India are reported failing across all the key performance measures including cost, time and quality performances. Gunawan et al. performed a comparative study of the schedule overrun for various development projects across China, India, Bangladesh and Thailand and concluded that the average schedule overrun is highest for India - 55\% of actual schedule [16]. Reasons for these delays range from land acquisition, improper planning and budgeting, to poor coordination and monitoring of the projects [17]. 


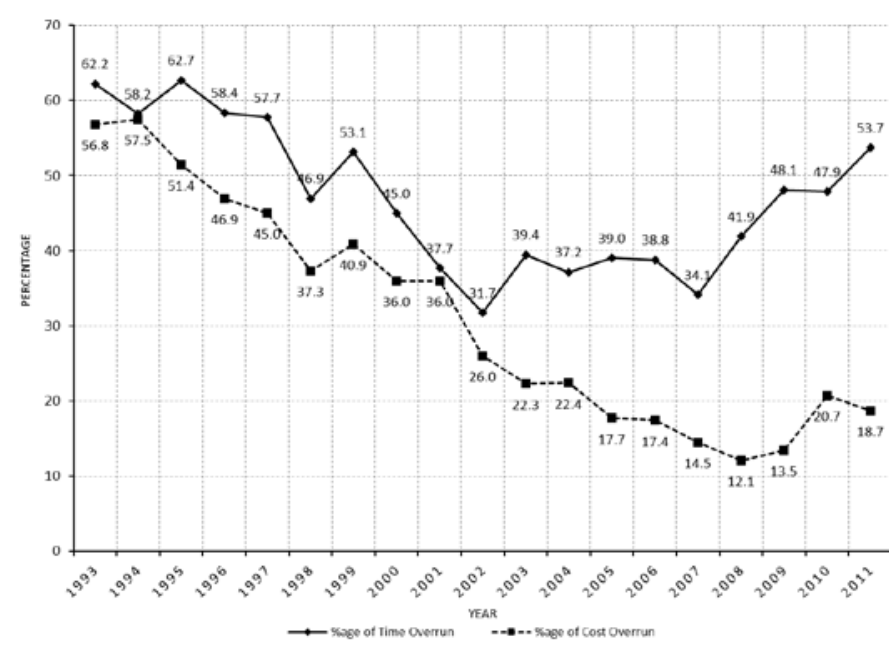

Figure 2. Percentage of delayed projects during the last 19 years [18]

The Ministry of Statistics and Programme Implementation (MOSPI) evaluated the time and cost overrun of 584 infrastructure projects for the period 1993-2011 and noted the values at the end the values of each financial year [18]. The analysis shows that 276 projects have contributed to time overrun ranging from 1-213 months with respect to their original schedule, while cost overruns have fallen steadily from $56.8 \%$ in 1993 to $18.7 \%$ in 2011 resulting in savings (Fig. 1). However, the cost overrun dropped steadily till 2007 and then began to rise. The lower limit of time and cost overrun are $30 \%$ and $10 \%$ respectively for $47.3 \%$ of public infrastructure projects, the values are still unacceptably high [19].

Harris el al. undertook a study to identify the construction delay causes for high-rise construction [20] in Indonesia. The study identified the predominant factors influencing time overruns/delays as design changes, poor labour productivity, inadequate planning and resource shortages. In everyday usage, the term high-rise commonly designates any tall building. A building is characterized as a high-rise building when it is considerably is higher than the surrounding structures. The vertical focus of the production processes and the small footprint of the ground plans mean that vertical transportation as the most common cause for bottlenecks. The specifications of various equipment like range and capacity of tower cranes, capacity of concrete pumps etc. are particularly important in this context [4].

High-rises have a decisive impact on the image of large cities, not only through the complete project, but also during the construction, conversion or demolition phases. Many different disciplines must deliver their services in an integrated manner during these periods [4]. In order to obtain the objective, clients, architects, expert planners, authorities and executing firms must complete a complex and challenging task that is associated with unique risks. Undeniably, high-rise buildings are also seen as wealth-generating mechanisms working in an urban economy. High-rise buildings are constructed largely because they can create large areas of real estate out of fairly small pieces of land.
It can be inferred from the past studies, the common causes for delay include delay causes like material delivery delay by vendors, poor coordination and monitoring of the projects and poor supervision among all other causes. Although, reasonable research has been performed to identify the causes of schedule overrun, only few of them have critically identified: (1) the important causes affecting real estate high-rise projects in the private sector; and (2) the causes of affecting such projects at the local level. The present research is target the knowledge gap with three objectives: (1) identifying the construction delay causes in India, (2) ranking the different causes of construction delay causes in high-rise construction and, (3) determining if the delay causes are different across a nation.

\section{MethodolOgy OF THE STUDY}

To address the objectives put forward above, primary data collection was performed using a structured questionnaire through the opinions of experts working on real estate high-rise projects in Bangalore, Kolkata, Mumbai and National Capital Region (NCR). The respondents for the survey were project stakeholders and the responses were collected using interviews and online questionnaire. The stakeholders included professionals working with real Estate developers, project management consultants (PMC), contractors and consultants. The respondents were identified using Snowball Sampling Method. Snowball sampling is a non-probability based sampling technique where research participants recruit other participants for a test or study. This type of sampling technique works through chain referral.

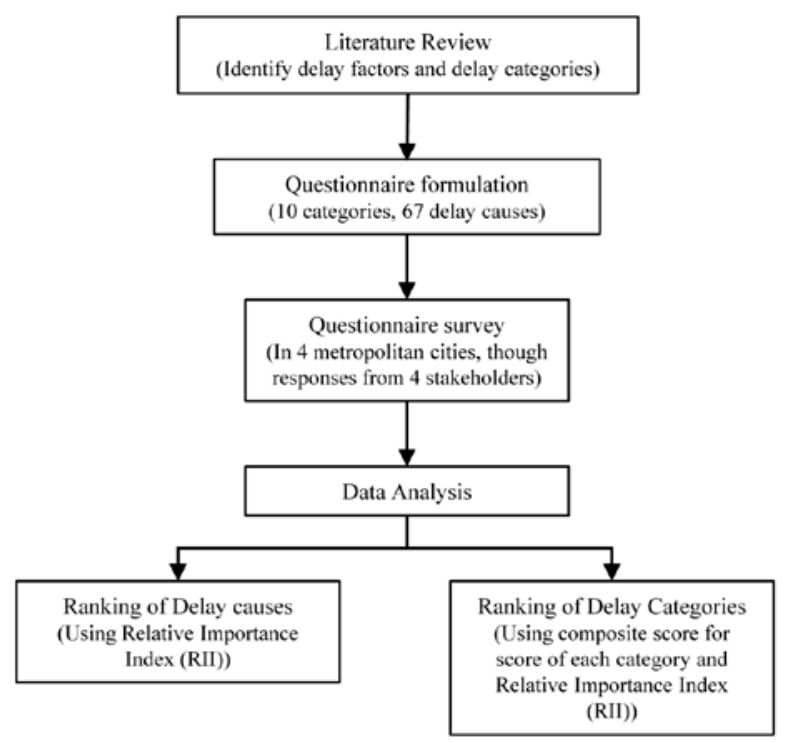

Figure 1. Methodology adopted for the study

Fig. 2 represents the methodology adopted for the study. Though literature review, data on delay categories and construction delay factors from review of past literature has been assembled. Through a critical review of over 15 studies performed on construction delay a total of 18 delay categories and 141 delay factors were identified. It was decided to reduce the total number of delay factors to a reasonable number. Researchers in the past had conducted similar surveys with 
around 70-80 delay factors in their questionnaire. The delay factors were reduced using a 2-stage elimination process:

1. Analysing the ranking and frequency of occurrence of delay factors and then shortlisting the delay factors by combining the top 67\% from ranking and frequency analysis. This stage gave 15 categories and 110 delay factors.

2. Checking for repetitions and combining the delay factors to prepare the final Questionnaire consisting of 10 categories and 67 delay factors.

The final questionnaire sent for acquiring the responses consisted of 10 delay categories and 67 delay causes, as displayed in Table I. The questionnaires were sent to the respondents through e-mail, online survey and personal interviews. The questionnaire used for collecting primary data regarding analysis of the delay factors will be divided into two sections:

1. Section A - This section requested general Information regarding the respondent, which included questions related to name, experience and tallest structure built.

2. Section B - This section focused on the factors influencing schedule overruns in high-rise construction projects. The respondents were requested to rate the delay causes on a scale of 1-5, with 5 signifying highest impact on construction delay.

TABLE I.

PROBLEM CATEGORIES IDENTIFIED FOR THE STUDY

\begin{tabular}{|c|l|c|}
\hline No. & \multicolumn{1}{|c|}{ Delay Category(Code) } & $\begin{array}{c}\text { Number of Delay Factors } \\
\text { in Category }\end{array}$ \\
\hline 1 & Material Related Delays (MAT) & 5 (MA1 to MA5) \\
\hline 2 & Equipment Related Causes (EQP) & 4 (EQ1 to EQ4) \\
\hline 3 & Labour Related Causes (LAB) & 6 (LA1 to LA6) \\
\hline 4 & Site Related Causes (SITE) & 5 (ST1 to ST5) \\
\hline 5 & Execution Related Causes (EXE) & 9 (EX1 to EX9) \\
\hline 6 & Contract Related Causes (CONT) & $11(\mathrm{CN1}$ to CN11) \\
\hline 7 & $\begin{array}{l}\text { Scheduling and Control Related } \\
\text { Causes (SCH) }\end{array}$ & 4 (SH1 to SH4) \\
\hline 8 & External Related Causes (EXT) & 6 (ET1 to ET6) \\
\hline 9 & Project Related Causes (PRJ) & 12 (PR1 to PR12) \\
\hline 10 & $\begin{array}{l}\text { Government Related Causes } \\
\text { (GOVN) }\end{array}$ & 5 (GV1 to GV5) \\
\hline
\end{tabular}

The data collected through the survey was analysed to identify the most important construction delay causes. All the items in the questionnaire were ranked using Relative Importance Index (RII), Equation (1) represents the expression. The RII value has a range of 0 to 1 , the higher value signifying a more important cause of schedule overrun. This method of ranking has also been used by Akintoye et al. [7], Khanh et al. [8], Aziz [9], Gunduz et al. [10], Sweis et al. [11], Vimonsatit et al. [12], Fugar et al. [13], Ogunlana et al. [14] and, Toor et al. [15].

$$
\begin{aligned}
R I I_{D F}=\frac{\sum w}{A \times N}, 0 \leq R I I_{D F} \leq 1 & (1) \\
\text { where, } w= & \text { Rating given by the } \\
& \text { respondents for each } \\
& \text { delay cause }(5 \text {, } \\
& \text { Extremely Important, } 4= \\
& \text { Very Important, } 3= \\
& \text { Moderately Important, } 2 \\
& =\text { Slightly Important, } 1= \\
& \text { Not Important). } \\
A= & \begin{array}{l}
\text { Highest weight in the } \\
\text { scale, } 5 \text { in this case. }
\end{array} \\
N= & \begin{array}{l}
\text { Total number } \\
\text { respondents. }
\end{array}
\end{aligned}
$$

For determining the ranking of the delay categories, a composite score (CS) was calculated each response under each of the categories, Equation (2) represents the formula. Using the relation used for RII, the composite scores were then analysed to determine the ranking.

$$
\begin{aligned}
& C S=\frac{W}{n}, 1 \leq C S \leq 5 \\
& \text { where, } W=\Sigma w \\
& =\text { Cumulative Rating for each } \\
& \text { category by each respondent } \\
& n=\text { Number of questions in the } \\
& \text { category. }
\end{aligned}
$$

The RII value for each category was then calculated for each category using Equation 3.

$$
\begin{aligned}
& R I I_{D C}=\frac{C S}{A \times N}, 0 \leq R I I_{D C} \leq 1 \\
& \text { where, } \quad W= \begin{array}{l}
\text { Rating for each category by } \\
\text { each respondent }
\end{array} \\
& A= \begin{array}{l}
\text { Highest weight in the scale, } \\
5 \text { in this case. }
\end{array} \\
& N=\begin{array}{l}
\text { Total number of of } \\
\text { respondents. }
\end{array}
\end{aligned}
$$

\section{DEMOGRAPHIC DETAILS OF THE RESPONDENTS}

A questionnaire survey was conducted in Kolkata, Bangalore, Mumbai and NCR (National Capital Region) from December 2015 to June 2016 by interviewing various senior level personnel working with various stakeholders working in high-rise projects. The names of the organisation were not recorded so as to remove any bias in the responses received. Of the 443 responses, $40 \%$ of the respondents were working with the developers (clients), 28\% were working with contractors, and an equal number of respondents were working with Consultants and PMC. Almost an equal number of stakeholders responded from all the 4 cities identified for the study (refer Table II). The respondents were selected based on their amount of experience in high-rise construction in the current location 
and were working in various decision making positions like project managers, project architect, company vice-president and other managerial positions. The current location refers to the location for which the data has been collected.

Out of the 107 responses received from Bangalore, 43\% of the respondents were working with developers, whereas $26 \%$ of the respondents were affiliated with contractors. The rest $34 \%$ of the respondents comprised of people working with consultants (architects and PMC). Over 83\% of the respondents had an experience of over 10 years in the construction industry, with over $40 \%$ of them having worked in the current location for over 10 years. Barely $2 \%$ of the survey being contributed by people having worked on buildings smaller than 10 floors, with almost $65 \%$ of the respondents having worked on buildings more than 15 floors.

In case of Kolkata, of the 114 responses received, almost $62 \%$ of the responses were received from people working with developers and contractors, with $22 \%$ of the responses coming from architects. Majority of the respondents (over 73\%) had an experience of over 10 years in the construction industry with almost $55 \%$ of them having utilised their experience in the current location itself. Almost of $90 \%$ of the respondents had worked on high-rise structures (over 10 floors) in various capacities and hardly $7 \%$ of the respondents had worked on structures lower than 10 floors.
Out of the 120 responses received from Mumbai, 40\% of the respondents were working with developers, whereas 33\% of the respondents were affiliated with contractors. The rest $27 \%$ of the respondents comprised of people working with consultants (architects and PMC). Over $90 \%$ of the respondents had an experience of over 10 years in the construction industry, with more than $60 \%$ of them having worked in the current location for over 10 years. None of the survey responses were contributed by people having worked on buildings smaller than 10 floors, with over $90 \%$ of the respondents having worked on buildings having more than 15 floors.

In case of NCR, of the 102 responses received, almost $70 \%$ of the responses were received from people working with developers and contractors, with $11 \%$ of the responses coming from architects. Majority of the respondents (over 83\%) had an experience of over 10 years in the construction industry with almost $58 \%$ of them having ustilised their experience in the current location itself. Almost of $80 \%$ of the respondents had worked on high-rise structures (over 10 floors) in various capacities and hardly $5 \%$ of the respondents had worked on structures lower than 10 floors.

A total of 443 respondents were responded from all across the four locations identified for the study. The summary of the demographic characteristics is reported in Table II.

TABLE II. DEMOGRAPHIC CHARACTERISTICS OF THE RESPONDENTS

\begin{tabular}{|c|c|c|c|c|c|c|c|c|c|c|}
\hline \multirow{2}{*}{ Characteristics } & \multicolumn{2}{|c|}{ Bangalore } & \multicolumn{2}{|c|}{ Kolkata } & \multicolumn{2}{|c|}{ Mumbai } & \multicolumn{2}{|c|}{ NCR } & \multicolumn{2}{|c|}{ Total } \\
\hline & $\mathbf{n}^{*}$ & $\%$ & $\mathbf{n}$ & $\%$ & $\mathbf{n}$ & $\%$ & $\mathbf{n}$ & $\%$ & $\mathbf{n}$ & $\%$ \\
\hline \multicolumn{11}{|l|}{ Role in construction } \\
\hline Client & 43 & $40 \%$ & 52 & $46 \%$ & 48 & $40 \%$ & 36 & $35 \%$ & 179 & $40 \%$ \\
\hline Architect/Consultant & 22 & $21 \%$ & 25 & $22 \%$ & 13 & $11 \%$ & 11 & $11 \%$ & 71 & $16 \%$ \\
\hline Contractor & 28 & $26 \%$ & 18 & $16 \%$ & 40 & $33 \%$ & 36 & $35 \%$ & 122 & $28 \%$ \\
\hline PMC & 14 & $13 \%$ & 19 & $17 \%$ & 19 & $16 \%$ & 19 & $19 \%$ & 71 & $16 \%$ \\
\hline \multicolumn{11}{|c|}{ Experience in Construction Industry } \\
\hline $0-5$ Years & 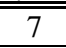 & $7 \%$ & 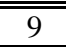 & $8 \%$ & 8 & $7 \%$ & 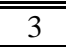 & $3 \%$ & 27 & $6 \%$ \\
\hline 5-10 Years & 11 & $10 \%$ & 22 & $19 \%$ & 3 & $3 \%$ & 13 & $13 \%$ & 49 & $11 \%$ \\
\hline 10-20 Years & 44 & $41 \%$ & 18 & $16 \%$ & 33 & $28 \%$ & 25 & $25 \%$ & 120 & $27 \%$ \\
\hline$>20$ Years & 45 & $42 \%$ & 65 & $57 \%$ & 76 & $63 \%$ & 61 & $60 \%$ & 247 & $56 \%$ \\
\hline \multicolumn{11}{|l|}{ Tallest Project Worked on } \\
\hline$<<10$ Floors & 2 & $2 \%$ & 8 & $7 \%$ & 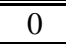 & $0 \%$ & 14 & $14 \%$ & 24 & $5 \%$ \\
\hline 10-15 Floors & 35 & $33 \%$ & 14 & $12 \%$ & 8 & $7 \%$ & 6 & $6 \%$ & 63 & $14 \%$ \\
\hline 15-25 Floors & 29 & $27 \%$ & 40 & $35 \%$ & 14 & $12 \%$ & 28 & $27 \%$ & 111 & $25 \%$ \\
\hline$>25$ Floors & 41 & $38 \%$ & 52 & $46 \%$ & 98 & $82 \%$ & 54 & $53 \%$ & 245 & $55 \%$ \\
\hline \multicolumn{11}{|l|}{ "Current location of Work } \\
\hline Bangalore & 107 & $100 \%$ & NA & NA & NA & NA & NA & NA & 107 & $24 \%$ \\
\hline Kolkata & $\mathrm{NA}$ & NA & 114 & $100 \%$ & $\mathrm{NA}$ & NA & $\mathrm{NA}$ & NA & 114 & $26 \%$ \\
\hline Mumbai & NA & NA & NA & NA & 120 & $100 \%$ & NA & NA & 120 & $27 \%$ \\
\hline NCR & NA & NA & NA & NA & $\mathrm{NA}$ & NA & 102 & $100 \%$ & 102 & $23 \%$ \\
\hline \multicolumn{11}{|c|}{ Experience in Current Location } \\
\hline $0-5$ Years & 22 & $21 \%$ & 18 & $16 \%$ & 19 & $16 \%$ & 23 & $23 \%$ & 82 & $19 \%$ \\
\hline 5-10 Years & 37 & $35 \%$ & 31 & $27 \%$ & 28 & $23 \%$ & 8 & $8 \%$ & 104 & $23 \%$ \\
\hline $10-20$ Years & 32 & $30 \%$ & 42 & $37 \%$ & 47 & $39 \%$ & 38 & $37 \%$ & 159 & $36 \%$ \\
\hline$>20$ Years & 16 & $15 \%$ & 23 & $20 \%$ & 26 & $22 \%$ & 33 & $32 \%$ & 98 & $22 \%$ \\
\hline
\end{tabular}

$*_{\mathrm{n}}=$ number of respondents 


\section{RESULTS OF RANKING OF THE DELAY CAUSES}

Table III lists the ranking Relative Importance Index (RII) and respective ranking of the delay causes for all the four locations and the overall ranking of the delay cause as ranked by the respondents on a 5-point rating scale.

The overall ranking of the delay cause as ranked by the respondents on a 5-point rating scale.

TABLE III. RII AND RANKING FOR DELAY CAUSES FOR ALL LOCATIONS

\begin{tabular}{|c|c|c|c|c|c|c|c|c|c|c|c|}
\hline \multicolumn{2}{|r|}{ Delay Factors } & \multicolumn{2}{|c|}{ Bangalore } & \multicolumn{2}{|c|}{ Kolkata } & \multicolumn{2}{|c|}{ Mumbai } & \multicolumn{2}{|c|}{ NCR } & \multicolumn{2}{|c|}{ Overall } \\
\hline & & RII & Rank & RII & Rank & RII & Rank & RII & Rank & RII & Rank \\
\hline MA1 & Shortage in market/Site & 0.585 & 59 & 0.472 & 57 & 0.550 & 60 & 0.586 & 53 & 0.547 & 60 \\
\hline MA2 & Procurement and storage & 0.619 & 51 & 0.553 & 27 & 0.640 & 42 & 0.592 & 51 & 0.601 & 41 \\
\hline МАЗ & $\begin{array}{l}\text { Loss of material due to misuse, } \\
\text { improper storage and theft }\end{array}$ & 0.546 & 65 & 0.525 & 39 & 0.452 & 67 & 0.512 & 65 & 0.507 & 66 \\
\hline MA4 & Quality & 0.604 & 54 & 0.574 & 15 & 0.513 & 65 & 0.596 & 50 & 0.570 & 57 \\
\hline MA5 & $\begin{array}{l}\text { Price fluctuation and changes in } \\
\text { material specifications }\end{array}$ & 0.680 & 31 & 0.546 & 30 & 0.612 & 46 & 0.718 & 17 & 0.636 & 27 \\
\hline EQ1 & Skill level of operators & 0.639 & 43 & 0.511 & 46 & 0.600 & 51 & 0.657 & 36 & 0.600 & 43 \\
\hline EQ2 & Equipment allocation & 0.621 & 50 & 0.493 & 55 & 0.555 & 58 & 0.696 & 23 & 0.587 & 50 \\
\hline EQ3 & Availability & 0.574 & 61 & 0.525 & 39 & 0.573 & 54 & 0.590 & 52 & 0.565 & 58 \\
\hline EQ4 & Faults/Maintenance & 0.589 & 58 & 0.544 & 31 & 0.535 & 62 & 0.508 & 67 & 0.544 & 62 \\
\hline LA1 & Productivity & 0.776 & 3 & 0.649 & 4 & 0.770 & 2 & 0.859 & 2 & 0.761 & 2 \\
\hline LA2 & Overtime & 0.628 & 47 & 0.495 & 54 & 0.647 & 39 & 0.555 & 61 & 0.582 & 51 \\
\hline LA3 & Skilled labour availability & 0.794 & 2 & 0.635 & 6 & 0.758 & 3 & 0.802 & 4 & 0.745 & 3 \\
\hline LA4 & Unskilled labour availability & 0.604 & 54 & 0.532 & 35 & 0.658 & 31 & 0.586 & 53 & 0.596 & 46 \\
\hline LA5 & Motivation & 0.680 & 31 & 0.561 & 24 & 0.645 & 41 & 0.698 & 21 & 0.644 & 24 \\
\hline LA6 & Disputes/strikes & 0.503 & 66 & 0.393 & 67 & 0.555 & 58 & 0.571 & 57 & 0.504 & 67 \\
\hline ST1 & Site Mobilisation & 0.665 & 36 & 0.542 & 33 & 0.653 & 36 & 0.678 & 28 & 0.633 & 30 \\
\hline ST2 & $\begin{array}{c}\text { Geophysical Conditions on site } \\
\text { (Water table, soil conditions, old } \\
\text { construction etc.) }\end{array}$ & 0.686 & 25 & 0.511 & 46 & 0.683 & 22 & 0.565 & 58 & 0.612 & 37 \\
\hline ST3 & $\begin{array}{c}\text { Physical conditions existing on } \\
\text { site (Existing trees, buildings etc.) }\end{array}$ & 0.561 & 63 & 0.496 & 52 & 0.685 & 21 & 0.576 & 56 & 0.581 & 52 \\
\hline ST4 & $\begin{array}{l}\text { Availability of site utilities for } \\
\text { construction (Water, electricity } \\
\text { etc.) }\end{array}$ & 0.598 & 56 & 0.416 & 65 & 0.563 & 56 & 0.645 & 39 & 0.553 & 59 \\
\hline ST5 & Site Access and surroundings & 0.660 & 38 & 0.477 & 56 & 0.667 & 28 & 0.598 & 49 & 0.600 & 42 \\
\hline EX1 & $\begin{array}{l}\text { Site management and supervision } \\
\text { by contractor }\end{array}$ & 0.727 & 10 & 0.628 & 7 & 0.728 & 7 & 0.775 & 6 & 0.713 & 5 \\
\hline EX2 & Construction method & 0.682 & 30 & 0.568 & 17 & 0.687 & 19 & 0.724 & 16 & 0.664 & 18 \\
\hline EX3 & $\begin{array}{l}\text { Preparation and approval of tests } \\
\text { and inspection }\end{array}$ & 0.585 & 59 & 0.451 & 63 & 0.527 & 63 & 0.627 & 46 & 0.544 & 61 \\
\hline EX4 & $\begin{array}{c}\text { Control of subcontractors by } \\
\text { general contractors in execution of } \\
\text { works }\end{array}$ & 0.720 & 13 & 0.602 & 11 & 0.688 & 18 & 0.727 & 13 & 0.683 & 14 \\
\hline EX5 & $\begin{array}{c}\text { Site accidents due to } \\
\text { negligence/lack of safety measures }\end{array}$ & 0.731 & 9 & 0.549 & 29 & 0.672 & 27 & 0.702 & 20 & 0.661 & 19 \\
\hline EX6 & $\begin{array}{l}\text { Sub-contractors site staff } \\
\text { availability }\end{array}$ & 0.705 & 18 & 0.554 & 26 & 0.652 & 37 & 0.663 & 35 & 0.642 & 25 \\
\hline EX7 & $\begin{array}{c}\text { Changing of sub-contractor during } \\
\text { project }\end{array}$ & 0.768 & 4 & 0.618 & 9 & 0.687 & 19 & 0.714 & 18 & 0.695 & 11 \\
\hline EX8 & $\begin{array}{l}\text { Rework due to mistakes in } \\
\text { construction }\end{array}$ & 0.684 & 28 & 0.567 & 19 & 0.622 & 44 & 0.741 & 10 & 0.650 & 22 \\
\hline EX9 & $\begin{array}{l}\text { Experience/Availability of } \\
\text { technical, managerial and } \\
\text { supervisory personnel of } \\
\text { contractor on site }\end{array}$ & 0.735 & 8 & 0.563 & 23 & 0.720 & 10 & 0.753 & 8 & 0.691 & 12 \\
\hline CN1 & $\begin{array}{c}\text { Conflicts between parties involved } \\
\text { in project }\end{array}$ & 0.634 & 46 & 0.544 & 31 & 0.568 & 55 & 0.622 & 47 & 0.590 & 48 \\
\hline CN2 & $\begin{array}{l}\text { Unrealistic Contract Durations } \\
\text { Initiated by Client }\end{array}$ & 0.712 & 16 & 0.619 & 8 & 0.715 & 14 & 0.739 & 11 & 0.695 & 10 \\
\hline
\end{tabular}




\begin{tabular}{|c|c|c|c|c|c|c|c|c|c|c|c|}
\hline \multirow{2}{*}{\multicolumn{2}{|c|}{ Delay Factors }} & \multicolumn{2}{|c|}{ Bangalore } & \multicolumn{2}{|c|}{ Kolkata } & \multicolumn{2}{|c|}{ Mumbai } & \multicolumn{2}{|c|}{ NCR } & \multicolumn{2}{|c|}{ Overall } \\
\hline & & RII & Rank & RII & Rank & RII & Rank & RII & Rank & RII & Rank \\
\hline CN3 & Contract Management & 0.686 & 25 & 0.530 & 37 & 0.678 & 24 & 0.675 & 29 & 0.641 & 26 \\
\hline CN4 & Joint ownership of project & 0.611 & 53 & 0.398 & 66 & 0.635 & 43 & 0.669 & 33 & 0.576 & 53 \\
\hline CN5 & $\begin{array}{c}\text { Organisation of } \\
\text { client/contractor/consultant }\end{array}$ & 0.658 & 39 & 0.540 & 34 & 0.658 & 31 & 0.631 & 42 & 0.622 & 34 \\
\hline CN6 & $\begin{array}{l}\text { Availability of professional } \\
\text { project management }\end{array}$ & 0.690 & 22 & 0.609 & 10 & 0.665 & 29 & 0.671 & 31 & 0.658 & 20 \\
\hline CN7 & $\begin{array}{l}\text { Financial incentive for contractor } \\
\text { to finish ahead of schedule }\end{array}$ & 0.680 & 31 & 0.504 & 51 & 0.677 & 25 & 0.680 & 27 & 0.634 & 29 \\
\hline CN8 & $\begin{array}{c}\text { Legal Disputes between parties in } \\
\text { the project }\end{array}$ & 0.624 & 48 & 0.433 & 64 & 0.612 & 46 & 0.629 & 45 & 0.573 & 56 \\
\hline CN9 & $\begin{array}{l}\text { Negotiations and obtaining of } \\
\text { contracts }\end{array}$ & 0.615 & 52 & 0.511 & 46 & 0.610 & 49 & 0.653 & 38 & 0.595 & 47 \\
\hline CN10 & $\begin{array}{c}\text { Effectiveness of construction } \\
\text { management }\end{array}$ & 0.718 & 14 & 0.584 & 13 & 0.718 & 12 & 0.688 & 25 & 0.677 & 17 \\
\hline CN11 & Low Awarded Bid Price & 0.699 & 19 & 0.565 & 22 & 0.725 & 8 & 0.867 & 1 & 0.710 & 7 \\
\hline SH1 & $\begin{array}{l}\text { Availability of database in } \\
\text { estimating activity duration and } \\
\text { resources }\end{array}$ & 0.697 & 20 & 0.505 & 50 & 0.655 & 35 & 0.690 & 24 & 0.635 & 28 \\
\hline SH2 & $\begin{array}{c}\text { Judgement and experience of } \\
\text { people involved in estimating time } \\
\text { and resources }\end{array}$ & 0.764 & 5 & 0.553 & 27 & 0.745 & 5 & 0.698 & 21 & 0.689 & 13 \\
\hline SH3 & $\begin{array}{l}\text { Project schedule monitoring } \\
\text { during construction }\end{array}$ & 0.684 & 28 & 0.521 & 42 & 0.700 & 16 & 0.725 & 15 & 0.656 & 21 \\
\hline SH4 & $\begin{array}{l}\text { Relationship between different } \\
\text { subcontractors' schedules }\end{array}$ & 0.718 & 14 & 0.589 & 12 & 0.720 & 10 & 0.775 & 6 & 0.698 & 9 \\
\hline 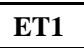 & 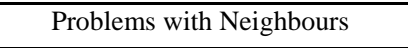 & 0.725 & 12 & 0.514 & 44 & 0.665 & 29 & 0.514 & 64 & 0.606 & 40 \\
\hline ET2 & Public Holidays/Festivals & 0.707 & 17 & 0.577 & 14 & 0.560 & 57 & 0.549 & 62 & 0.597 & 45 \\
\hline ET3 & $\begin{array}{c}\text { Factors out of } \\
\text { control/Uncertainties }\end{array}$ & 0.656 & 40 & 0.532 & 35 & 0.612 & 46 & 0.561 & 59 & 0.590 & 48 \\
\hline ET4 & Rain/Inclement weather & 0.688 & 23 & 0.568 & 17 & 0.658 & 31 & 0.557 & 60 & 0.619 & 36 \\
\hline ET5 & Social and Culture factor & 0.566 & 62 & 0.514 & 44 & 0.550 & 60 & 0.535 & 63 & 0.541 & 63 \\
\hline ET6 & Price Fluctuation & 0.664 & 37 & 0.567 & 19 & 0.593 & 52 & 0.671 & 31 & 0.621 & 35 \\
\hline PR1 & Payment of Completed Works & 0.727 & 10 & 0.574 & 15 & 0.743 & 6 & 0.786 & 5 & 0.706 & 8 \\
\hline PR2 & $\begin{array}{l}\text { Financial Difficulties to parties } \\
\text { involved in project }\end{array}$ & 0.750 & 7 & 0.637 & 5 & 0.748 & 4 & 0.812 & 3 & 0.735 & 4 \\
\hline PR3 & Necessary variations of Works & 0.675 & 34 & 0.525 & 39 & 0.647 & 39 & 0.682 & 26 & 0.630 & 31 \\
\hline PR4 & $\begin{array}{l}\text { Waiting time for preparation and } \\
\text { approval of drawings }\end{array}$ & 0.753 & 6 & 0.558 & 25 & 0.707 & 15 & 0.706 & 19 & 0.679 & 15 \\
\hline PR5 & $\begin{array}{l}\text { Quality Assessment and Quality } \\
\text { Control in design }\end{array}$ & 0.675 & 34 & 0.526 & 38 & 0.620 & 45 & 0.631 & 42 & 0.612 & 38 \\
\hline PR6 & Flow of information/instruction & 0.686 & 25 & 0.511 & 46 & 0.657 & 34 & 0.669 & 33 & 0.629 & 32 \\
\hline PR7 & $\begin{array}{l}\text { Experience/Availability of site } \\
\text { staff and regular inspection by } \\
\text { consultants }\end{array}$ & 0.645 & 41 & 0.463 & 60 & 0.577 & 53 & 0.622 & 47 & 0.574 & 54 \\
\hline PR8 & Obsolete Technology & 0.479 & 67 & 0.470 & 58 & 0.502 & 66 & 0.633 & 41 & 0.518 & 65 \\
\hline PR9 & Suspension of work & 0.622 & 49 & 0.461 & 61 & 0.680 & 23 & 0.675 & 29 & 0.609 & 39 \\
\hline PR10 & $\begin{array}{l}\text { Involvement/association of parties } \\
\text { through Project Life }\end{array}$ & 0.645 & 41 & 0.496 & 52 & 0.603 & 50 & 0.655 & 37 & 0.598 & 44 \\
\hline PR11 & Design Team Experience & 0.559 & 64 & 0.458 & 62 & 0.648 & 38 & 0.631 & 42 & 0.574 & 55 \\
\hline PR12 & Design related issues & 0.688 & 23 & 0.518 & 43 & 0.677 & 25 & 0.727 & 13 & 0.650 & 22 \\
\hline GV1 & $\begin{array}{l}\text { Obtaining permits from } \\
\text { Government }\end{array}$ & 0.809 & 1 & 0.658 & 3 & 0.883 & 1 & 0.745 & 9 & 0.776 & 1 \\
\hline GV2 & Political Condition & 0.639 & 43 & 0.700 & 1 & 0.722 & 9 & 0.643 & 40 & 0.678 & 16 \\
\hline GV3 & $\begin{array}{c}\text { Bureaucracy in Project-owner } \\
\text { operation }\end{array}$ & 0.639 & 43 & 0.567 & 19 & 0.692 & 17 & 0.584 & 55 & 0.622 & 33 \\
\hline GV4 & $\begin{array}{l}\text { Building codes used in design of } \\
\text { projects }\end{array}$ & 0.598 & 56 & 0.467 & 59 & 0.515 & 64 & 0.512 & 65 & 0.522 & 64 \\
\hline GV5 & Economic Condition & 0.697 & 20 & 0.700 & 1 & 0.718 & 12 & 0.737 & 12 & 0.713 & 5 \\
\hline
\end{tabular}


In order to study the asperity of rating received by each delay category, composite score of the delay constructs was calculated and ranked. Table IV presents the RII and ranking of the delay constructs. The results of the RII calculated for each of the locations are discussed in the subsequent sections to understand the various causes affecting construction schedule.

TABLE IV. RII AND RANKING FOR DELAY CONSTRUCTS FOR ALL LOCATIONS

\begin{tabular}{|c|c|c|c|c|c|c|c|c|c|c|}
\hline \multirow{2}{*}{ Delay Constructs } & \multicolumn{2}{|c|}{ Bangalore } & \multicolumn{2}{|c|}{ Kolkata } & \multicolumn{2}{|c|}{ Mumbai } & \multicolumn{2}{|c|}{ NCR } & \multicolumn{2}{|c|}{ Overall } \\
\hline & RII & Rank & RII & Rank & RII & Rank & RII & Rank & RII & Rank \\
\hline Material Related Causes (MAT) & 0.607 & 9 & 0.532 & 6 & 0.553 & 10 & 0.601 & 10 & 0.572 & 10 \\
\hline Equipment Related Causes (EQP) & 0.606 & 10 & 0.512 & 9 & 0.566 & 9 & 0.613 & 8 & 0.574 & 9 \\
\hline Labour Related Causes (LAB) & 0.664 & 6 & 0.538 & 5 & 0.672 & 3 & 0.678 & 5 & 0.639 & 4 \\
\hline Site Related Causes (SITE) & 0.634 & 8 & 0.485 & 10 & 0.650 & 7 & 0.613 & 9 & 0.596 & 7 \\
\hline Execution Related Causes (EXE) & 0.704 & 2 & 0.562 & 2 & 0.659 & 5 & 0.703 & 2 & 0.660 & 3 \\
\hline Contract Related Causes (CONT) & 0.666 & 5 & 0.529 & 7 & 0.658 & 6 & 0.684 & 3 & 0.634 & 5 \\
\hline $\begin{array}{l}\text { Scheduling and Control Related } \\
\text { Causes (SCH) }\end{array}$ & 0.716 & 1 & 0.541 & 4 & 0.677 & 2 & 0.718 & 1 & 0.670 & 1 \\
\hline External Related Causes (EXT) & 0.668 & 4 & 0.547 & 3 & 0.667 & 4 & 0.637 & 7 & 0.596 & 8 \\
\hline Project Related Causes (PRJ) & 0.659 & 7 & 0.519 & 8 & 0.640 & 8 & 0.665 & 6 & 0.626 & 6 \\
\hline Government Related Causes (GOVN) & 0.677 & 3 & 0.618 & 1 & 0.707 & 1 & 0.680 & 4 & 0.662 & 2 \\
\hline
\end{tabular}

V. DisCUSSION - MAJOR CONSTRUCTION DELAY FACTORS IN INDIA

Table III illustrates the consolidated ranking of the top 15 delay factors for the four locations studied and the overall ranking of the delay causes. The delay causes have been arranged according to the occurrence in the different delay categories. The cells pertaining to delay causes which do not feature in the most important causes have been highlighted grey.

TABLE V. RII AND RANKING OF MOST IMPORTANT 15 DELAY FACTORS FOR ALL THE LOCATIONS STUDIED

\begin{tabular}{|c|c|c|c|c|c|c|c|c|c|c|c|}
\hline \multirow{2}{*}{\multicolumn{2}{|c|}{ Delay Factors }} & \multicolumn{2}{|c|}{ Bangalore } & \multicolumn{2}{|c|}{ Kolkata } & \multicolumn{2}{|c|}{ Mumbai } & \multicolumn{2}{|c|}{ NCR } & \multicolumn{2}{|c|}{ Overall } \\
\hline & & RII & Rank & RII & Rank & RII & Rank & RII & Rank & RII & Rank \\
\hline MA4 & Material Quality & & & 0.574 & 15 & & & & & & \\
\hline LA1 & Labour Productivity & 0.776 & 3 & 0.649 & 4 & 0.77 & 2 & 0.859 & 2 & 0.761 & 2 \\
\hline LA3 & Skilled labour availability & 0.794 & 2 & 0.635 & 6 & 0.758 & 3 & 0.802 & 4 & 0.745 & 3 \\
\hline EX1 & Site management and supervision by contractor & 0.727 & 10 & 0.628 & 7 & 0.728 & 7 & 0.775 & 6 & 0.713 & 5 \\
\hline EX4 & $\begin{array}{l}\text { Control of subcontractors by general contractors } \\
\text { in execution of works }\end{array}$ & 0.72 & 13 & 0.602 & 11 & & & 0.727 & 13 & 0.683 & 14 \\
\hline EX5 & $\begin{array}{l}\text { Site accidents due to negligence/lack of safety } \\
\text { measures }\end{array}$ & 0.731 & 9 & & & & & & & & \\
\hline EX7 & Changing of sub-contractor during project & 0.768 & 4 & 0.618 & 9 & & & & & 0.695 & 11 \\
\hline EX8 & Rework due to mistakes in construction & & & & & & & 0.741 & 10 & & \\
\hline EX9 & $\begin{array}{l}\text { Experience/Availability of technical, managerial } \\
\text { and supervisory personnel of contractor on site }\end{array}$ & 0.735 & 8 & & & 0.72 & 10 & 0.753 & 8 & 0.691 & 12 \\
\hline CN2 & Unrealistic Contract Durations Initiated by Client & & & 0.619 & 8 & 0.715 & 14 & 0.739 & 11 & 0.695 & 10 \\
\hline CN6 & Availability of professional project management & & & 0.609 & 10 & & & & & & \\
\hline CN10 & Effectiveness of construction management & 0.718 & 14 & 0.584 & 13 & 0.718 & 12 & & & & \\
\hline CN11 & Low Awarded Bid Price & & & & & 0.725 & 8 & 0.867 & 1 & 0.71 & 7 \\
\hline SH2 & $\begin{array}{l}\text { Judgement and experience of people involved in } \\
\text { estimating time and resources }\end{array}$ & 0.764 & 5 & & & 0.745 & 5 & & & 0.689 & 13 \\
\hline SH3 & Project schedule monitoring during construction & & & & & & & 0.725 & 15 & & \\
\hline SH4 & $\begin{array}{l}\text { Relationship between different subcontractors' } \\
\text { schedules }\end{array}$ & 0.718 & 14 & 0.589 & 12 & 0.72 & 10 & 0.775 & 6 & 0.698 & 9 \\
\hline ET1 & Problems with Neighbours & 0.725 & 12 & & & & & & & & \\
\hline ET2 & Public Holidays/Festivals & & & 0.577 & 14 & & & & & & \\
\hline PR1 & Payment of Completed Works & 0.727 & 10 & 0.574 & 15 & 0.743 & 6 & 0.786 & 5 & 0.706 & 8 \\
\hline PR2 & $\begin{array}{l}\text { Financial Difficulties to parties involved in } \\
\text { project }\end{array}$ & 0.75 & 7 & 0.637 & 5 & 0.748 & 4 & 0.812 & 3 & 0.735 & 4 \\
\hline PR4 & $\begin{array}{l}\text { Waiting time for preparation and approval of } \\
\text { drawings }\end{array}$ & 0.753 & 6 & & & 0.707 & 15 & & & 0.679 & 15 \\
\hline PR12 & Design related issues & & & & & & & 0.727 & 13 & & \\
\hline GV1 & Obtaining permits from Government & 0.809 & 1 & 0.658 & 3 & 0.883 & 1 & 0.745 & 9 & 0.776 & 1 \\
\hline GV2 & Political Condition & & & 0.7 & 1 & 0.722 & 9 & & & & \\
\hline GV5 & Economic Condition & & & 0.7 & 1 & 0.718 & 12 & 0.737 & 12 & 0.713 & 5 \\
\hline
\end{tabular}

The observations listed in Table III have been displayed graphically in Fig. 3. 


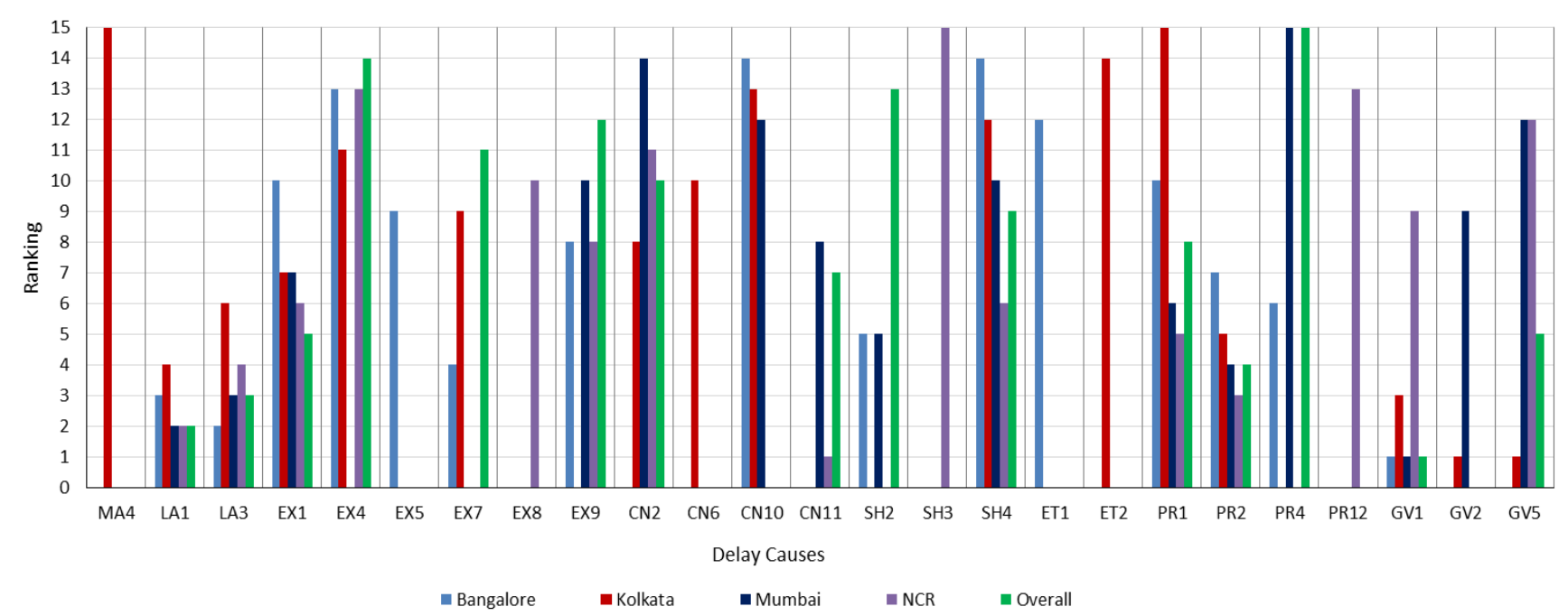

Figure 3. Graph showing the ranking of major delay causes for all the locations studied

In case of Bangalore, the most important delay factor is found to be related to obtaining permits from government. The second and third most important factors are related to the labour related issues which is justified by the paucity of labour in and around the location. Uniquely, site accidents due to negligence features ninth among the most important delay causes identified.

As can be seen from Table III, the top 3 factors in Kolkata are related to government related issues, which is synonymous to the local scenario and which is one agenda that is rarely in the hands of the project stakeholders. Two issues pertaining to labour related issues rank 4 and 6 , which is agreeable to the views of the respondents, many of whom have expressed their concern that though the region has sufficient number of construction labour, but they prefer to migrate to other favourable locations for better opportunities.

According to the discussions with the respondents in Mumbai, it was pointed out that the building by-laws changed time to time and obtaining relevant permissions from the concerned authorities was a tough task. It is synonymous with the observations from the survey as delay factors related to obtaining permits from government is the most important cause. Factors like skilled labour availability and labour productivity are primarily important as well, as according to discussion with project managers, there is a paucity of local labour in and around Mumbai. It must be noted that the observations are similar to the ones observed for Bangalore.

It must be noted that the obtaining permits from the government (GV1) features as one of the top delay factors in all the cities studied, though it is rather lowly ranked at 9 for NCR. This delay cause seems to affect construction schedule almost everywhere in the country.

Delay factors labour productivity (LA1), skilled labour availability (LA3) and financial difficulties to parties involved (PR2) are ranked 2, 3 and 4 in the overall ranking and their ranking ranges from ranks 2-7 for all the other locations as well. Concerns regarding labour productivity and skill availability had been aptly raised by respondents during the interviews also. Addressing this problem in the initial phase can help in reducing construction delay. Proper training of skilled labour can help in increasing the productivity, which in turn can reduce schedule overrun. It should also be noted that factors from delays categories like material related, equipment related, site related and external related issues do not feature in the highly ranked delay causes at the overall level. The ground for this could be due to these causes are local issues and can be rectified before the commencement of the project.

At the overall level, obtaining permits from government (GV1), labour productivity (LA1), skilled labour availability (LA3), financial difficulties to parties involved in project (PR2) and site management and supervision by contractor (EX1) feature as the top 5 problems affecting construction schedule. It is also noticeable that the top 15 factors listed in the table feature from 7 categories originally identified, namely, 4 from execution related, 3 from project related whereas 2 each from government related, scheduling and control related, labour related, and contract related causes.

As can be observed that most of the delay factors that affect schedule in the across metropolitan cities in India generally feature in the individual cities studied as well, there are still a few delay causes that are particular to certain locations. These causes are listed in Table IV. These causes need to be addressed at the local level to earn better benefits in the construction.

TABLE VI. DELAY FACTORS IN THE FOUR LOCATIONS DISTINCT FROM OVERALL CAUSES

\begin{tabular}{|c|c|c|c|}
\hline Bangalore & Kolkata & Mumbai & NCR \\
\hline \hline $\begin{array}{c}\text { Site accidents } \\
\text { due to } \\
\text { negligence/lack } \\
\text { of safety } \\
\text { measures } \\
\text { (EX5) }\end{array}$ & $\begin{array}{c}\text { Political Condition } \\
\text { (GV2) }\end{array}$ & $\begin{array}{c}\text { Political } \\
\text { Condition } \\
\text { (GV2) }\end{array}$ & $\begin{array}{c}\text { Rework due to } \\
\text { mistakes in } \\
\text { construction } \\
\text { (EX8) }\end{array}$ \\
\hline $\begin{array}{c}\text { Problems with } \\
\text { Neighbours } \\
\text { (ET1) }\end{array}$ & $\begin{array}{c}\text { Availability of } \\
\text { professional } \\
\text { project } \\
\text { management }\end{array}$ & $\begin{array}{c}\text { Effectiveness } \\
\text { of } \\
\text { construction } \\
\text { management }\end{array}$ & $\begin{array}{c}\text { Design related } \\
\text { issues (PR12) }\end{array}$ \\
\hline \multicolumn{3}{|c}{} \\
\hline
\end{tabular}




\begin{tabular}{|c|c|c|c|}
\hline Bangalore & Kolkata & Mumbai & NCR \\
\hline \hline $\begin{array}{c}\text { Effectiveness } \\
\text { of construction } \\
\text { management } \\
\text { (CN10) }\end{array}$ & $\begin{array}{c}\text { Effectiveness of } \\
\text { construction } \\
\text { management } \\
\text { (CN10) }\end{array}$ & (CN10) & \\
\hline & $\begin{array}{c}\text { Project schedule } \\
\text { monitoring } \\
\text { during } \\
\text { construction } \\
\text { (SH3) }\end{array}$ \\
\hline & $\begin{array}{c}\text { Public } \\
\text { (E) } \\
\text { (ET2) }\end{array}$ & & \\
\hline & $\begin{array}{c}\text { Material Quality } \\
\text { (MA4) }\end{array}$ & & \\
\hline
\end{tabular}

VI. DISCUSSION - MAJOR CATEGORIES OF CONSTRUCTION DELAY IN INDIA

Table $\mathrm{V}$ illustrates the ranking of the delay categories for the four locations studied and the overall ranking of the delay categories. The delay causes have been arranged according to the ascending order of ranking for the overall rating.

TABLE VII. RANKING OF DELAY CATEGORIES ACROSS THE LOCATIONS STUDIED

\begin{tabular}{|c|c|c|c|c|c|}
\hline $\begin{array}{c}\text { Delay } \\
\text { Constructs }\end{array}$ & Bangalore & Kolkata & Mumbai & NCR & Overall \\
\hline $\begin{array}{l}\text { Scheduling and } \\
\text { Control Related } \\
\text { Causes (SCH) }\end{array}$ & 1 & 4 & 2 & 1 & 1 \\
\hline $\begin{array}{l}\text { Government } \\
\text { Related Causes } \\
(\text { GOVN) }\end{array}$ & 3 & 1 & 1 & 4 & 2 \\
\hline $\begin{array}{l}\text { Execution } \\
\text { Related Causes } \\
(\text { EXE) }\end{array}$ & 2 & 2 & 5 & 2 & 3 \\
\hline $\begin{array}{l}\text { Labour Related } \\
\text { Causes (LAB) }\end{array}$ & 6 & 5 & 3 & 5 & 4 \\
\hline $\begin{array}{l}\text { Contract } \\
\text { Related Causes } \\
(\mathrm{CONT}) \\
\end{array}$ & 5 & 7 & 6 & 3 & 5 \\
\hline $\begin{array}{l}\text { Project Related } \\
\text { Causes (PRJ) }\end{array}$ & 7 & 8 & 8 & 6 & 6 \\
\hline $\begin{array}{l}\text { Site Related } \\
\text { Causes (SITE) }\end{array}$ & 8 & 10 & 7 & 9 & 7 \\
\hline $\begin{array}{l}\text { External } \\
\text { Related Causes } \\
(\mathrm{EXT})\end{array}$ & 4 & 3 & 4 & 7 & 8 \\
\hline $\begin{array}{l}\text { Equipment } \\
\text { Related Causes } \\
\text { (EQP) }\end{array}$ & 10 & 9 & 9 & 8 & 9 \\
\hline $\begin{array}{l}\text { Material } \\
\text { Related Causes } \\
\text { (MAT) }\end{array}$ & 9 & 6 & 10 & 10 & 10 \\
\hline
\end{tabular}

The observations listed in Table $\mathrm{V}$ have been displayed

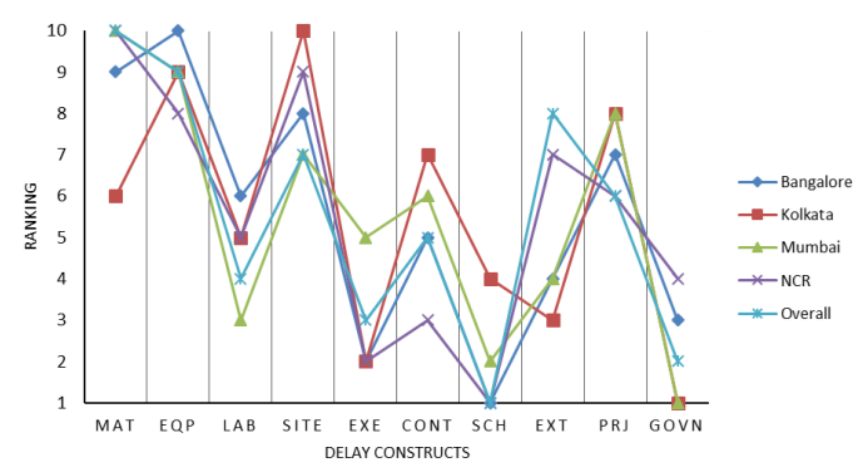

Figure 4. Graph comparing the overall ranking of delay categories against the locations graphically in Fig. 4.

Scheduling and control related category features at the top for overall delay category and ranks as the top priority for both Bangalore and NCR, whereas it ranks at 4th for Kolkata and 2nd for Mumbai. Scheduling is an important task in any construction and more so in case of high-rise construction projects. Though in Kolkata it does not rank right at the top, it still is an important aspect to be looked into

Delay categories such as government related (overall rank 2) and execution related (overall rank 3) feature as top priority for all the locations with rankings varying between 1-4 for government related and rankings 2-5 for execution related. According to discussions with the respondents, it was observed than many privately owned construction projects get delayed due to changes in government related issues and this reflects in the observations from the study. Execution is an important part of a building construction project and needs to be looked into at appropriate times during the construction process.

Equipment related causes rank 9 overall and, ranks almost at the same level for the other locations. It can be inferred that present day projects are rather well versed in the modern construction techniques using construction equipment and is not of much concern for any of the locations.

Material related delay category ranks lowest overall and ranks near the bottom for most of the locations except Kolkata. According to discussions with the respondents, the material supplies in Kolkata are controlled by local business monopoly groups and creates a major hindrance in the process. A better coordination in material supply can help in achieving proposed schedule in projects.

\section{CONCLUSION AND RECOMMENDATIONS}

A questionnaire consisting of 67 delay causes categorised under 10 groups was used to probe the most significant factors causing delay in real estate high-rise projects in a few major cities across India. Responses were taken on a 5-point scale from various professionals working with real estate developers, contractors, consultants and project management consultants (PMC). Around 100 responses were received from each of the locations. The importance of the various delay causes and delay categories was calculated.

Overall it can be observed that though the most important delay appear similar, there is difference in the individual ranking of the delay causes. There are a few delay causes which are unique to specific locations. Overall, the most important delay category has been identified to scheduling and control related and it features among the five most important cause for all the locations as well. In case of a highrise construction, scheduling plays an important role. It should be noted that the observations of this research have a regional focus.

\section{ACKNOWLEDGMENT}

The authors would like to thank the various professional working at different capacities in construction projects across India. The authors would also like to acknowledge the 
knowledge sharing done by professionals working with SPCL, Tata Housing.

\section{REFERENCES}

[1] K. N. Jha, "Determinants of Construction Project Success in India", vol. 23. Dordrecht: Springer Netherlands, 2013.

[2] S. A. Assaf and S. Al-Hejji, "Causes of delay in large construction projects,” Int. J. Proj. Manag., vol. 24, no. 4, pp. 349-357, May 2006.

[3] "GDP Contribution of Different Sectors in 2011-12: Annual Report 2011-12", Ministry of Statistics and Programme Implementation, Government of India, pp. 105-106, 2012.

[4] J. Eisele, and E. Kloft, "High-rise manual: Typology and design, construction and technology”, Birkhauser-Publishers for architecture, 2002.

[5] Peter, K., Paul, O., Gary, H., and Frank C. (1997). "Factors influencing construction time and cost overruns on high-rise projects in Indonesia", Journal of Construction Management and Economic. Vol. 15, No.1, pp. 83-94.

[6] González, P., González, P., Molenaar, D.Ph,K., Asce, M., and Orozco, F. (2014). "Analysis of causes of delay and time performance in construction project”, Journal of Construction Engineering Management, vol. 140, pp. 1-9.

[7] Z. Shehu, I. R. Endut, and A. Akintoye, "Factors contributing to project time and hence cost overrun in the Malaysian construction industry," J. Financ. Manag. Prop. Constr., vol. 19, no. 1, pp. 55-75, 2014.

[8] R. Mizanur, L. Y. Dai, and H. D. Khanh, "Investigating Main Causes for Schedule Delay in Construction Projects in Bangladesh,” no. 3, 2014

[9] R. F. Aziz, "Ranking of delay factors in construction projects after Egyptian revolution,” Alexandria Eng. J., vol. 52, no. 3, pp. 387-406, 2013.

[10] M. Gündüz, Y. Nielsen, and M. Özdemir, "Quantification of Delay Factors Using the Relative Importance Index Method for Construction
Projects in Turkey,” J. Manag. Eng., vol. 29, no. April, pp. 133-139, 2012.

[11] G. J. Sweis, R. Sweis, M. A. Rumman, R. A. Hussein, and S. E. Dahiya, "Cost Overruns in Public Construction Projects: The Case of Jordan,” J. Am. Sci., vol. 9, no. 7, pp. 134-141, 2013.

[12] K. Wong and V. Vimonsatit, "A study of the factors affecting construction time in Western Australia," Curtain Univ., vol. 7, no. 40, pp. 3390-3398, 2012.

[13] F. D. K. Fugar and A. B. Agyakwah-baah, "Delays in Building Construction Projects in Ghana,” Australasian J. Constr. Econ. Build., vol. 10, no. 1/2, pp. 103-116, 2010.

[14] V. T. Luu, S.-Y. Kim, N. Van Tuan, and S. O. Ogunlana, "Quantifying schedule risk in construction projects using Bayesian belief networks," Int. J. Proj. Manag., vol. 27, no. 1, pp. 39-50, 2009.

[15] S.U.R. Toor and S. Ogunlana, "Problems causing delays in major construction projects in Thailand,” Constr. Manag. Econ., vol. 26, no. 4, pp. 395-408, 2008.

[16] K. Ahsan and I. Gunawan, "Analysis of cost and schedule performance of international development projects,” Int. J. Proj. Manag., vol. 28, no. 1, pp. 68-78, 2010.

[17] H. Doloi, A. Sawhney, K. C. Iyer, and S. Rentala, "Analysing factors affecting delays in Indian construction projects,” Int. J. Proj. Manag., vol. 30, no. 4, pp. 479-489, 2012.

[18] Ministry of Statistics and Programme Implementation (2012). GDP contribution of different sectors in 2011-12: Annual Report 2011-12, Government of India.

[19] A. P. Sanyal, S. P. Bhattacharya, \& Sutapa Das, "Cost and schedule overrun in infrastructure projects: the Indian Scenario”, Abacus, vol. 09, no. 01, pp. 32-38, 2014.

[20] P. F. Kaming , P. O. Olomolaiye , G. D. Holt \& F. C. Harris, "Factors influencing construction time and cost overruns on high-rise projects in Indonesia," Construction Management and Economics, vol. 15, no. 1, pp. 83-94, 1997. . 